\title{
OPEN Effects of soil texture and nitrogen fertilisation on soil bacterial community structure and nitrogen uptake in flue-cured tobacco
}

\author{
Meiying Zheng ${ }^{1}$, Pei Zhu ${ }^{1}$, Jiayu Zheng ${ }^{1}$, Lin Xue ${ }^{2}$, Qifa Zhu ${ }^{2}$, Xianjie Cai ${ }^{3}$, Sen Cheng ${ }^{3}$, \\ Zhongfeng Zhang ${ }^{1}$, Fanyu Kong ${ }^{1}$ \& Jiguang Zhang ${ }^{1 \bowtie}$
}

We tested the hypothesis that soil texture and nitrogen $(\mathrm{N})$ fertilisation are the primary factors regulating the $\mathrm{N}$ cycle and soil bacterial community structure. The response of soil bacterial communities to $\mathrm{N}$ fertilisation in different textured soils might help in identifying the specific underlying mechanism and hence management of $\mathrm{N}$ fertiliser application in fields. We examined how $\mathbf{N}$ fertiliser accumulates in flue-cured tobacco and influences soil bacterial community structure in different textured soils. We conducted plot and micro-plot experimental measurements of $\mathrm{N}$ content in soil and tobacco samples using the $\mathrm{KNO}_{3}{ }^{15} \mathrm{~N}$ isotope technique. Soil bacterial community structure was determined using high-throughput sequencing of $16 \mathrm{~S}$ rRNA. Nitrogen absorption and utilisation by tobacco plants were highest in sandy loam soils, followed by loam soil and clay loam. The ability of clay loam to supply $\mathbf{N}$ was weak during the plant growth period. Absence of fertilisation could reduce bacterial abundance in soils to various degrees. Bacterial diversity was higher in sandy loam soil than in loam soil and clay loam. Soil texture and $\mathbf{N}$ fertilisation significantly affected soil bacterial community structure and diversity. Proteobacteria, Acidobacteria, Firmicutes, Bacteroidetes, Actinobacteria, and Chloroflexi were the dominant bacterial phyla, while Bacillus, Nitrobacter, Nitrosospira, Nitrospira, and Rhizobium were the primary $\mathrm{N}$ transformation bacteria at the genus level in all treatments. However, relative abundances differed with $\mathbf{N}$ fertiliser application, which could lead to differential $\mathrm{N}$ availability and $\mathrm{N}$ use efficiency of tobacco among soil types. We conclude that both soil texture and $\mathrm{N}$ fertilisation influence $\mathrm{N}$ accumulation and distribution in flue-cured tobacco and thus regulate soil bacterial communities. $\mathrm{N}$ fertiliser application in sandy loam soil should be strictly controlled for its higher $\mathrm{N}$ use efficiency, soil bacterial abundance, and diversity.

Nitrogen $(\mathrm{N})$ plays an important role in crop production in terrestrial ecosystems ${ }^{1}$. The $\mathrm{N}$ cycle is a key component of ecosystems, and application of $\mathrm{N}$ fertiliser can significantly improve agricultural productivity and crop yields ${ }^{2,3}$, so application of $\mathrm{N}$ fertiliser is increasing globally ${ }^{4}$. However, the excessive and unreasonable application of $\mathrm{N}$ fertilizer leads to low nitrogen use efficiency. Large amounts of fertiliser $\mathrm{N}$ are lost to the environment through runoff, leaching, ammonia volatilization, nitrification denitrification and other ways ${ }^{5-7}$, resulting in nonpoint source pollution and other serious environmental problems. Developing strategies to address these issues is thus crucial. Understanding the impacts of soil texture and $\mathrm{N}$ fertiliser application on $\mathrm{N}$ cycling will provide further insight into ways these problems can be solved.

Soil texture is a key component of $\mathrm{N}$ and $\mathrm{N}$-cycle dynamics in soil, soil surface texture plays an important role on $\mathrm{N}$ mineralization ${ }^{8}$. Nyiraneza et al., who studied the yield and quality of spring wheat on different soil textures such as clay, soil, and sand in eastern Canada, found that soil texture influenced $\mathrm{N}$ conversion and subsequent wheat quality, and that crop yield and $\mathrm{N}$ uptake was highest in wheat grown on loam ${ }^{9}$. Thus, determining the appropriate application rates of $\mathrm{N}$ fertilisers for enhancing crop productivity and improving soil quality is critical.

Microorganisms are essential components of soil ecosystems and are commonly used as indicators of soil quality $^{10}$. The soil $\mathrm{N}$ cycle is closely related to microbial community structure, and microbial activity is the primary driver of soil $\mathrm{N}$ cycling ${ }^{11}$. Assimilation of inorganic $\mathrm{N}$ by soil microorganisms is key to maintaining soil

\footnotetext{
${ }^{1}$ Tobacco Research Institute, Chinese Academy of Agricultural Sciences, Qingdao 266101, China. ${ }^{2}$ Southern Anhui Tobacco Leaf Co. Ltd., Xuan cheng 242000, China. ${ }^{3}$ Shanghai Tobacco Group Limited Liability Company, Shanghai 200082, China. ${ }^{\varpi}$ email: zhangjiguang@caas.cn
} 


\begin{tabular}{|c|c|c|c|c|c|c|c|}
\hline Texture & $\begin{array}{l}\text { Soil organic } \\
\text { carbon }(\mathbf{g} / \mathbf{k g})\end{array}$ & $\begin{array}{l}\text { Alkali-hydrolysable N } \\
(\mathrm{mg} / \mathrm{kg})\end{array}$ & Olsen-P (mg/kg) & $\mathrm{NH}_{4} \mathrm{Ac}-\mathrm{K}(\mathrm{mg} / \mathrm{kg})$ & $\begin{array}{l}\text { Clay } \\
\text { particle }<0.002 \mathrm{~mm} \\
(\%)\end{array}$ & $\begin{array}{l}\text { Slit particle } \\
0.002 \sim 0.02 \mathrm{~mm}(\%)\end{array}$ & $\begin{array}{l}\text { Sand } \\
\text { particle }>0.02 \mathrm{~mm} \\
(\%)\end{array}$ \\
\hline Clay loam & 24.80 & 188.42 & 33.78 & 346.73 & 31.38 & 38.97 & 29.64 \\
\hline Loam soil & 24.50 & 208.25 & 40.57 & 565.29 & 20.16 & 33.71 & 46.13 \\
\hline Sandy loam & 24.27 & 196.88 & 45.85 & 548.33 & 18.67 & 23.29 & 58.04 \\
\hline
\end{tabular}

Table 1. Physical and chemical properties of different texture soils.

$\mathrm{N}$ and reducing fertiliser $\mathrm{N}$ loss in the environment ${ }^{12}$. Previous studies have shown that soil microbial abundance and community structure are often altered by fertiliser application ${ }^{13,14}$. However, no clear trend in how soil microbial community structure responds to $\mathrm{N}$ fertilisers has been deduced ${ }^{15}$. For example, Liu et al. found that in an intensive agricultural system, nitrate leaching plays an important role in the formation of bacterial communities in the subsoil soil under long-term fertilization ${ }^{16}$, while $\mathrm{N}$ was reported to be the most important factor influencing ammonia-oxidizing microorganisms in systems under long-term $\mathrm{N}$ fertilisation regimes ${ }^{17}$. Soil texture can also influence soil microbial community structure. Clay content was found to affect bacterial diversity, with results demonstrating that bacterial communities indirectly mediating soil texture ${ }^{18,19}$. The effects of $\mathrm{N}$ fertiliser on soil microbial communities in different soil texture types under similar climate conditions remains uncertain. As such, the objective of our study was to provide further insight into how soil communities respond to $\mathrm{N}$ fertilisers.

Tobacco is among the most important commercial crops globally and is widely grown in China across numerous types of soil ${ }^{20}$, and both tobacco yield and quality are influenced by soil $\mathrm{N}$ supply and $\mathrm{N}$ fertiliser application ${ }^{21}$. We hypothesised that soil texture and $\mathrm{N}$ application are the main factors driving $\mathrm{N}$ cycling and bacterial community structure in soil. To test this, we used ${ }^{15} \mathrm{~N}$ isotope and high-throughput sequencing technology to investigate the effects of $\mathrm{N}$ fertiliser application on soil bacterial community structure, $\mathrm{N}$ accumulation, and $\mathrm{N}$ distribution in flue-cured tobacco grown in three types of soil texture.

\section{Methods}

Site and soil characteristics. This study was conducted in the Xuanzhou district $\left(30^{\circ} 40 \mathrm{~N}, 118^{\circ} 46 \mathrm{E}\right)$, Xuancheng City, Anhui Province, China. This area has a typical monsoon climate, with an average annual temperature of $15.8{ }^{\circ} \mathrm{C}$ and an average annual rainfall of $1324.8 \mathrm{~mm}$. The mean annual sunshine time is $2072.5 \mathrm{~h}$, and the mean annual frost-free period is 228 days. The main soil type of the region is hydromorphic paddy soil formed from river alluvial parent material. Based on previous research on tobacco yield and quality and soils in this area, we selected three tobacco fields in the Huayang River basin of the Xuanzhou District that feature different soil textures. These soil textures consisted of clay loam (CL; the village of Xizha, located far from the Huayang River), loam (LS; the village of Huangdu, located near to the Huayang River), and sandy loam (SL; the village of Xintian, located very close to the Huayang River). Defining characteristics of the three soil types are presented in Table 1.

Field experiment. A total of nine treatments on three tobacco plots were used for the experiment, with three treatments—no fertilizer (CK), conventional fertilisation (T1), and no N fertilisation (T2) - applied per soil texture. The experiment consisted of a completely randomised design with three replicates. The area of each replicate plot was $96 \mathrm{~m}^{2}(6 \mathrm{~m} \times 16 \mathrm{~m})$, with each plot separated by ridges to prevent cross-contamination among treatments. Flue-cured tobacco (Nicotiana tabacum cv. Yunyan 97) was used in the experiment. The fertilisers used included potassium nitrate $\left(13.5 \% \mathrm{~N}, 44.5 \% \mathrm{~K}_{2} \mathrm{O}\right)$, calcium magnesium phosphate fertiliser $\left(12 \% \mathrm{P}_{2} \mathrm{O}_{5}\right)$, potassium sulfate $\left(50 \% \mathrm{~K}_{2} \mathrm{O}\right)$, and commercial organic fertiliser (40\% organic matter). The same amount of $\mathrm{P}$ and K-based fertilisers were used in each treatment, with P-based fertiliser $\left(\mathrm{P}_{2} \mathrm{O}_{5}\right)$ applied at a rate of $180 \mathrm{~kg} / \mathrm{ha}$ and $\mathrm{K}$-based fertiliser $\left(\mathrm{K}_{2} \mathrm{O}\right)$ applied at a rate of $337.5 \mathrm{~kg} / \mathrm{ha}$. In the $\mathrm{CK}$ treatment, no fertiliser was applied. In the $\mathrm{T} 1$ treatment, a pure $\mathrm{N}$-based fertiliser was applied at a rate of $112.5 \mathrm{~kg} / \mathrm{ha}$. In the T2 treatment, no $\mathrm{N}$ fertiliser was applied. In addition, $70 \%$ of the amount of chemical fertiliser and all the organic fertiliser were applied as a basal application, and the remaining $30 \%$ of chemical fertiliser was applied as a topdressing fertiliser in the experiment. Field management metrics and measurements were consistent among all treatments at the three test sites.

${ }^{15} \mathrm{~N}$ micro-plot experiment. Field plots and micro-plots were combined in this experiment, with ${ }^{15} \mathrm{~N}$ micro-plots established within field plots and treated with conventional fertiliser under each soil type. The area of each micro-plot was $0.6 \mathrm{~m}^{2}(1.2 \mathrm{~m} \times 0.5 \mathrm{~m})$ and contained one flue-cured tobacco plant. Fifteen micro-plots were established within each field plot. A plastic partitioning board was used to isolate the surrounding microarea (insertion depth of the board $=50 \mathrm{~cm}$ ). Nitrogen, $\mathrm{P}$, and $\mathrm{K}$ fertilisers were applied separately to the microplots, with amount conversions the same as that for field plots. The $\mathrm{KNO}_{3}$ fertiliser composed of $10 \%{ }^{15} \mathrm{~N}$ that was applied to the micro-plots was provided by the Shanghai Chemical Research Institute.

Experiment sampling and testing. Three tobacco plants with similar growth potentials were selected and sampled at each tobacco growth stage, consisting of 38 days (rosette stage), 53 days (budding stage), 64 days (topping stage), and 103 days (mature stage) following transplantation of the plants in 2013. The tobacco samples 
were prepared in three parts (roots, stems, and leaves) each time. Dry weights were determined via oven drying $65^{\circ} \mathrm{C}$ for $30 \mathrm{~min}$. After passing the samples through a $0.15 \mathrm{~mm}$ sieve, total $\mathrm{N}$ and ${ }^{15} \mathrm{~N}$ contents were determined using the Kjeldahl method (K-05 automatic $\mathrm{N}$ analyser) and a $\mathrm{ZHT}-\mathrm{O}_{2}$ mass spectrometer, respectively. All methods were performed in accordance with the relevant guidelines and regulations.

Three soil samples (0-20 cm topsoil) were collected from each plot at 103 days (mature stage) after transplantation of flue-cured tobacco. Five subsamples were combined into one sample to form a composite sample and stored at $-40^{\circ} \mathrm{C}$ until further analyses of the soil bacterial community.

Calculation of $\mathbf{N}$ uptake. The amount and proportion of $\mathrm{N}$ uptake by plants from the soil were calculated using Chen's equation ${ }^{22}$ :

$$
\begin{gathered}
\mathrm{W}_{\mathrm{N}}=\mathrm{W}_{1} \times \mathrm{C}_{1} ; \\
\% \mathrm{~N} d f f=\frac{{ }^{15} \mathrm{~N}_{1}}{{ }^{15} \mathrm{~N}_{2}} \times 100 ; \\
\mathrm{N} d f f=\mathrm{W}_{\mathrm{N}} \mathrm{W} \mathrm{N} d f f \\
\mathrm{~N} d f s=\mathrm{W}_{\mathrm{N}}=(1-\% \mathrm{~N} d f f) ; \\
\mathrm{R}_{\mathrm{N}}=\frac{\mathrm{N} d f f}{\mathrm{~W}_{0} \times \mathrm{C}_{0}} \times 100 \%
\end{gathered}
$$

where $W_{N}$ is the total $\mathrm{N}$ accumulation in flue-cured tobacco samples, $W_{1}$ is the flue-cured tobacco sample dry weight, $C_{1}$ is the flue-cured tobacco sample $\mathrm{N}$ content, ${ }^{15} N_{1}$ is the flue-cured tobacco sample ${ }^{15} \mathrm{~N}$ atom percentage over, ${ }^{15} \mathrm{~N}_{2}$ is the fertiliser ${ }^{15} \mathrm{~N}$ atom percentage over, $\% N d f f$ is the fertiliser $\mathrm{N}$ as a percentage of total $\mathrm{N}, \mathrm{Ndff}$ is the flue-cured tobacco fertiliser $\mathrm{N}$ accumulation, $N d f s$ is the soil $\mathrm{N}$ accumulation, $R_{N}$ is the seasonal $\mathrm{N}$ use efficiency, $W_{0}$ is the fertiliser weight, and $C_{0}$ is the $\mathrm{N}$ content percentage in the fertiliser.

Analysis of soil bacterial community structure. Total genomic DNA was extracted from soil samples using a Power Soil DNA extraction kit (Mobio, USA). The final DNA concentration and purification were determined using a NanoDrop 2000 UV-vis spectrophotometer (Thermo Scientific, USA), and DNA concentration and purity were monitored on $1 \%$ agarose gels.

PCR amplification. To amplify the bacterial DNA fragments, two primer sets were chosen. The V3-V4 hypervariable regions of the bacterial $16 \mathrm{~S}$ rRNA gene were amplified with primers $338 \mathrm{~F}\left(5^{\prime}\right.$-ACTCCTACGGGA GGCAGCA-G-3') and 806R (5'-GGACTACHVGGGTWTCTAAT-3' ${ }^{23}$. The PCR mixture $(30 \mu \mathrm{L})$ contained $10 \mathrm{ng}$ template DNA, $15 \mu \mathrm{L}$ of Phusion High-Fidelity PCR Master Mix (New England Biolabs, USA), and $0.2 \mu \mathrm{M}$ of forward and reverse primers. The PCR conditions were as follows: $98^{\circ} \mathrm{C}$ for $1 \mathrm{~min}$, followed by 30 cycles of $98^{\circ} \mathrm{C}$ for $10 \mathrm{~s}, 50^{\circ} \mathrm{C}$ for $30 \mathrm{~s}, 72{ }^{\circ} \mathrm{C}$ for $60 \mathrm{~s}$, and $72{ }^{\circ} \mathrm{C}$ for $5 \mathrm{~min}$.

Processing of sequencing data. Raw fastq files were demultiplexed, quality-filtered using Trimmomatic, and merged using FLASH. Operational taxonomic units (OTUs) were clustered with $97 \%$ similarity cut off using UPARSE (version 7.1), and chimeric sequences were identified and removed using UCHIME. The taxonomy of each16SrRNA gene sequence was analysed using the ribosomal database project (RDP) classifier algorithm against the Silva $16 \mathrm{~S}$ rRNA database set to a confidence threshold of $70 \%$. Bacteria were then identified to the genus level. A representative sequence was selected from each OTU for the downstream analysis. Richness and diversity indices (Sobs, abundance-based coverage estimator [ACE], Chaol, Shannon, and Simpson) were also calculated. Both the mode of fertiliser application and soil texture were found to significantly affect bacterial communities (ANOVA).

Statistical analysis. Data processing and mapping were performed using Excel 2017, and ANOVA and multiple comparisons were performed using SPSS software (version 19.0). Cluster analysis was preceded by principal component analysis (PCA), which was applied to reduce the dimensions of the original variables using the QIIME software package.

\section{Results}

Accumulation and distribution of $\mathbf{N}$ in flue-cured tobacco growing in different soils. Accumulation dynamics of $\mathrm{N}$ in different soils. Nitrogen gradually increased in loam soil, clay loam, and sandy loam soils with plant growth (Fig. 1), attaining a maximum at the mature-plant stage $(2.10 \mathrm{~g} / \mathrm{plant}, 1.43 \mathrm{~g} / \mathrm{plant}$, and $2.90 \mathrm{~g} /$ plant, respectively). Nitrogen accumulation was lower in plants grown in clay loam than in plants grown in loam soil and sandy loam during the entire growth period, indicating that the $\mathrm{N}$ supply capacity of clay loam was relatively weak, and tobacco plants grown in this soil had the lowest levels of $\mathrm{N}$ uptake and utilisation. The $\mathrm{N}$ uptake and accumulation in flue-cured tobacco grown in loam soil and sandy loam were basically the same before the ceiling stage, but at the mature stage, $\mathrm{N}$ accumulation was significantly higher in plants grown in sandy loam than in plants grown in loam soil and clay loam $(\mathrm{P}<0.05)$. 


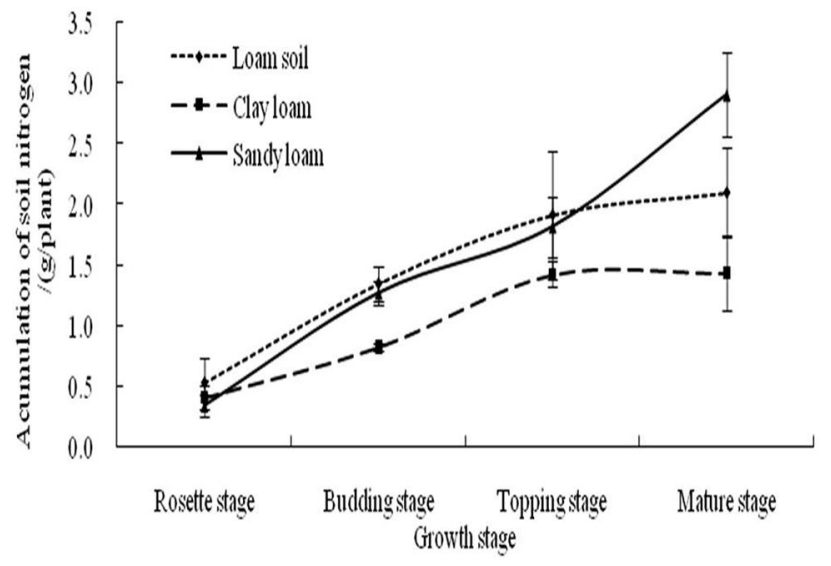

Figure 1. Accumulation dynamics of $\mathrm{N}$ in different soils.

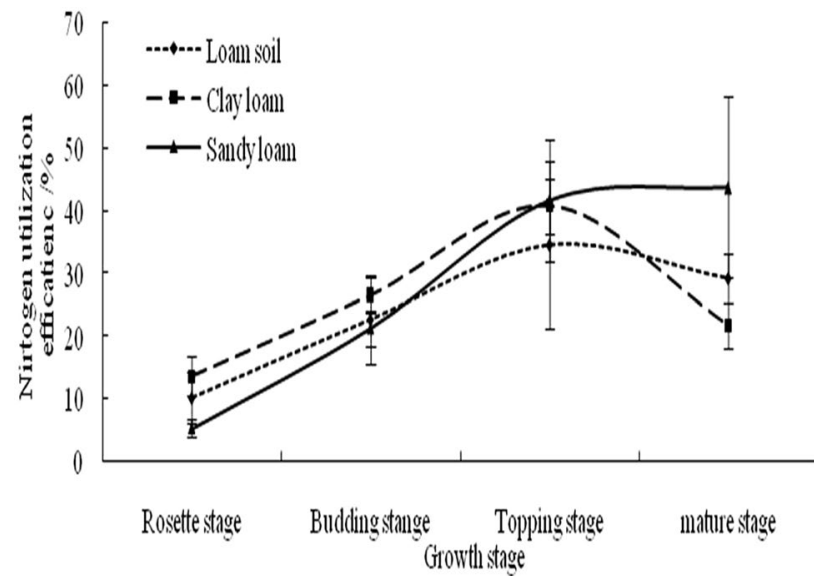

Figure 2. N use efficiency of flue-cured tobacco in different texture soils.

Nitrogen use efficiency of flue-cured tobacco in different texture soils. Flue-cured tobacco N use efficiency was similar among plants grown in clay loam and loam soils (Fig. 2); in both soils, $\mathrm{N}$ use efficiency improved steadily from the rosette stage to the ceiling stage, at which point it reached a maximum $(40.7 \%$ and $34.5 \%$, respectively). The $\mathrm{N}$ use efficiency of flue-cured tobacco grown in clay loam decreased significantly after reaching the ceiling stage. At the mature stage, $\mathrm{N}$ use efficiency of plants grown in clay loam and loam soils fell to $21.7 \%$ and $29.2 \%$, respectively.

In sandy loam, $\mathrm{N}$ use efficiency of flue-cured tobacco increased during the growth period, from $5.3 \%$ at the rosette stage to $43.7 \%$ at the mature stage. We observed significant differences between $\mathrm{N}$ use efficiency between tobacco grown in sandy loam and in clay loam $(\mathrm{P}<0.05)$, an indication that different soil textures had a significant effect on tobacco $\mathrm{N}$ uptake and utilisation during the growing phase. In sandy loam soil, tobacco $\mathrm{N}$ use efficiency was lower in the early growth stages and gradually increased over the course of the growth period, whereas that of plants grown in clay soil and loam was lower in the later growth stages than in the earlier growth stages.

$\mathbf{N}$ accumulation in different organs of flue-cured tobacco grown in different soils. Prior to the ceiling stage, no significant differences were observed in $\mathrm{N}$ accumulation in the roots of flue-cured tobacco grown in soils of different textures $(\mathrm{P}>0.05)$, as shown in Table 2. Following the ceiling stage, however, $\mathrm{N}$ accumulation in the roots was significantly higher in plants grown in loam soil and sandy loam than in plants grown in clay loam $(\mathrm{P}<0.05)$. At the mature stage, $\mathrm{N}$ accumulation in the roots of plants grown in loam soil, clay loam, and sandy loam was $0.82 \mathrm{~g} / \mathrm{plant}, 0.40 \mathrm{~g} /$ plant, and $0.70 \mathrm{~g} /$ plant, respectively. $\mathrm{N}$ accumulation in the stems of tobacco grown in all three soils increased with growth phase. At the rosette stage, $\mathrm{N}$ accumulation in the stems of plants grown in clay loam was significantly higher than in plants grown in loam soil and sandy loam $(\mathrm{P}<0.05)$; from the ceiling stage to the mature stage, $\mathrm{N}$ uptake by tobacco grown in sandy loam increased, reaching a maximum $(1.62 \mathrm{~g})$ at the mature stage, whereas $\mathrm{N}$ absorption ceased in stems of tobacco grown in loam soil. Changes in $\mathrm{N}$ accumulation in leaves of tobacco grown in loam soil and clay loam were consistent from the rosette to the mature stage, and maximum $\mathrm{N}$ accumulation in leaves of tobacco grown in these two soils occurred in the ceiling stage $(2.82 \mathrm{~g} /$ plant and $2.72 \mathrm{~g} /$ plant, respectively); values fell rapidly after this stage, however. Prior to 


\begin{tabular}{|l|l|l|l|l|l|}
\hline Part & Texture & Rosette stage & Budding stage & Ceiling stage & Mature stage \\
\hline \multirow{4}{*}{ Root } & Clay loam & $0.09 \pm 0.02 \mathrm{a}$ & $0.20 \pm 0.03 \mathrm{a}$ & $0.35 \pm 0.09 \mathrm{a}$ & $0.40 \pm 0.03 \mathrm{~b}$ \\
\cline { 2 - 6 } & Loam soil & $0.06 \pm 0.02 \mathrm{a}$ & $0.21 \pm 0.07 \mathrm{a}$ & $0.48 \pm 0.16 \mathrm{a}$ & $0.82 \pm 0.08 \mathrm{a}$ \\
\cline { 2 - 6 } & Sandy loam & $0.06 \pm 0.02 \mathrm{a}$ & $0.24 \pm 0.02 \mathrm{a}$ & $0.39 \pm 0.10 \mathrm{a}$ & $0.70 \pm 0.14 \mathrm{a}$ \\
\hline \multirow{4}{*}{ Stalk } & Clay loam & $0.21 \pm 0.08 \mathrm{a}$ & $0.42 \pm 0.05 \mathrm{a}$ & $0.89 \pm 0.11 \mathrm{a}$ & $0.93 \pm 0.06 \mathrm{~b}$ \\
\cline { 2 - 6 } & Loam soil & $0.09 \pm 0.02 \mathrm{~b}$ & $0.59 \pm 0.18 \mathrm{a}$ & $0.96 \pm 0.21 \mathrm{a}$ & $1.29 \pm 0.39 \mathrm{ab}$ \\
\cline { 2 - 6 } & Sandy loam & $0.09 \pm 0.04 \mathrm{~b}$ & $0.45 \pm 0.06 \mathrm{a}$ & $0.81 \pm 0.17 \mathrm{a}$ & $1.62 \pm 0.39 \mathrm{a}$ \\
\hline \multirow{3}{*}{ Leaves } & Clay loam & $0.6 \pm 0.21 \mathrm{a}$ & $1.86 \pm 0.12 \mathrm{a}$ & $2.72 \pm 0.34 \mathrm{a}$ & $1.45 \pm 0.48 \mathrm{a}$ \\
\cline { 2 - 6 } & Loam soil & $1.02 \pm 0.43 \mathrm{a}$ & $1.96 \pm 0.27 \mathrm{a}$ & $2.82 \pm 1.32 \mathrm{a}$ & $1.80 \pm 0.78 \mathrm{a}$ \\
\cline { 2 - 6 } & Sandy loam & $0.52 \pm 0.12 \mathrm{a}$ & $1.90 \pm 0.11 \mathrm{a}$ & $3.21 \pm 0.84 \mathrm{a}$ & $3.32 \pm 0.84 \mathrm{a}$ \\
\hline
\end{tabular}

Table 2. The $\mathrm{N}$ accumulation of various flue-cured tobacco organs at different growth stages (g/plant). Values followed by different letters in a column are significant among treatments at the $5 \%$ level.

\begin{tabular}{|c|c|c|c|c|c|}
\hline Texture & Fertilizer & Chaol & ACE & Shannon & Simpson \\
\hline \multirow{3}{*}{ Clay loam } & $\mathrm{CK}$ & 1574 & 1582 & 3.65 & 0.22 \\
\hline & $\mathrm{T} 1$ & 2131 & 2129 & 4.96 & 0.05 \\
\hline & $\mathrm{T} 2$ & 1452 & 1496 & 4.12 & 0.15 \\
\hline \multirow{3}{*}{ Loam soil } & CK & 1529 & 1863 & 5.48 & 0.03 \\
\hline & $\mathrm{T} 1$ & 2305 & 2486 & 5.63 & 0.03 \\
\hline & $\mathrm{T} 2$ & 2095 & 2348 & 4.8 & 0.06 \\
\hline \multirow{3}{*}{ Sandy loam } & $\mathrm{CK}$ & 2308 & 2336 & 5.22 & 0.04 \\
\hline & $\mathrm{T} 1$ & 2272 & 2224 & 5.74 & 0.025 \\
\hline & $\mathrm{T} 2$ & 2400 & 2463 & 6.16 & 0.015 \\
\hline \multicolumn{6}{|l|}{ Two-way ANOVA } \\
\hline Texture(T) & & $* * *$ & $* * *$ & $* * *$ & $* * *$ \\
\hline N Fertilization $(\mathrm{N})$ & & $* * *$ & $* * *$ & $* * *$ & $* * *$ \\
\hline Interaction $(\mathrm{T} \times \mathrm{N})$ & & $* * *$ & $* * *$ & $* * *$ & $* * *$ \\
\hline
\end{tabular}

Table 3. The influence of fertilizer and soil texture on indexes of richness and diversity of bacteria community, as obtained from the pyrosequencing analysis. Different letters in the same column indicate significant differences $(\mathrm{P}<0.05)$ among treatments. Significance levels: ${ }^{* * *} \mathrm{P}<0.001$.

the budding stage, $\mathrm{N}$ accumulation in leaves of plants grown in sandy loam was lower than in plants grown in loam soil and clay loam, and gradually increased after this stage, reaching the highest level (3.32 g/plant) at the mature stage.

Effects of soil texture and $\mathbf{N}$ fertilisation on soil bacterial community diversity and structure. Richness and alpha diversity indices of soil bacterial communities. The effects of soil texture and $\mathrm{N}$ fertilisation on soil bacteria richness and diversity are shown in Table 3. In the control treatment (CK), the bacterial community richness (Chaol and ACE) of sandy loam was higher than that of loam soil and clay loam, whereas in the N fertilisation treatments (T1 and T2), Chaol and ACE indices were higher for sandy loam and loam soil than clay loam. Chaol and ACE were also higher in loam soil and clay loam soils under the T1 treatment than the T2 and CK treatments, whereas for sandy loam soils, these indices were highest under the T2 treatment, followed in order by the $\mathrm{CK}$ and $\mathrm{T} 1$ treatments. These results suggest that $\mathrm{N}$ fertilisation can increase bacterial community richness in loam and clay loam soils but reduce bacterial community richness in sandy loam soil. Shannon and Simpson indices were used to investigate bacterial community diversity. In the CK treatment, the Shannon index was highest in loam soil and lowest in clay loam soil, whereas in the T1 treatment, it was highest in sandy loam and lowest in clay loam soils, with a similar trend o observed in the T2 treatment. This pattern indicated that bacterial diversity was lowest in clay loam. In contrast, the Simpson index exhibited an opposite trend to that of the Shannon index, indicating that bacterial diversity was greatest in clay loam soil regardless of $\mathrm{N}$ fertilisation. Results of ANOVA testing indicated that both $\mathrm{N}$ fertilisation and soil texture significantly affected bacterial community diversity and structure.

Beta diversity analysis of bacterial community structure. The results of a PCA based on the OTU levels are shown in Fig. 3. Using PCA, it was possible to extract two axes that reflected the differences between the samples. The PCA suggested an obvious separation of the bacterial communities among the different treatments, indicating that the bacterial communities in soils with different textures differed significantly under the same fertilisation treatments. In sandy loam and loam soils, bacterial communities were similar under T1 and T2 conditions, but both differed considerably from CK, whereas in clay loam soil, the bacterial communities of 


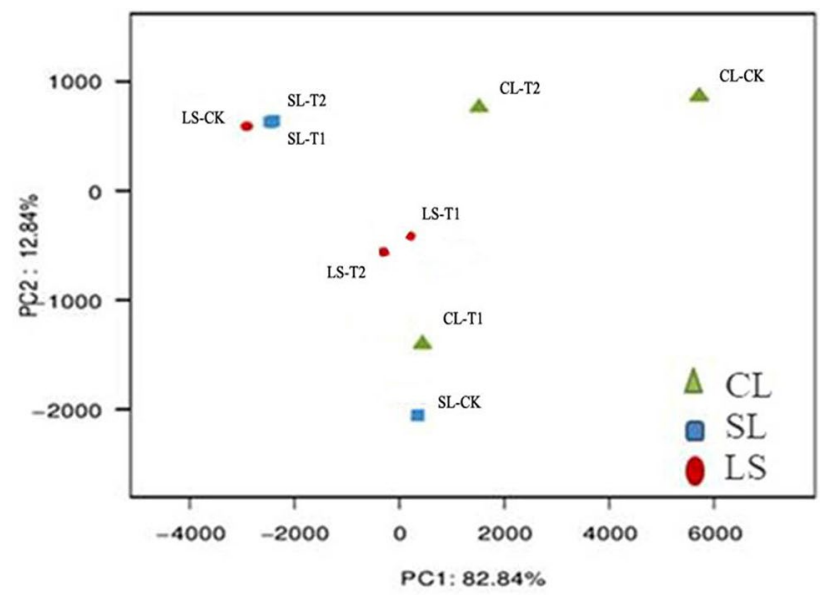

Figure 3. PCA analysis of different treatments.

\begin{tabular}{|c|c|c|c|c|c|c|c|c|c|}
\hline \multirow[b]{2}{*}{ Taxonomy } & \multicolumn{9}{|c|}{ Treatment } \\
\hline & CL-CK & CL-T1 & CL-T2 & LS-CK & LS-T1 & LS-T2 & SL-CK & SL-T1 & SL-T2 \\
\hline Phylum & 50.9 & 35.2 & 41.2 & 33.6 & 34.8 & 32.1 & 38.9 & 28.3 & 24.0 \\
\hline Class & 50.8 & 20.3 & 41.1 & 21.6 & 17.9 & 25.4 & 17.5 & 28.0 & 20.5 \\
\hline Order & 50.6 & 20.0 & 40.9 & 17.6 & 17.5 & 25.3 & 17.1 & 14.3 & 12.3 \\
\hline Family & 49.4 & \begin{tabular}{|l|}
19.7 \\
\end{tabular} & \begin{tabular}{|l|}
39.8 \\
\end{tabular} & 17.2 & 17.2 & 24.7 & 16.8 & 14.0 & 12.1 \\
\hline Genus & 46.6 & 18.6 & 37.8 & 16.4 & 16.5 & 23.5 & 15.8 & 18.9 & 20.6 \\
\hline Species & 46.2 & 43.0 & 37.5 & 43.7 & 42.8 & 39.1 & 45.2 & 37.1 & 42.3 \\
\hline
\end{tabular}

Table 4. Relative abundance of dominant communities at different taxonomic levels, $\%$.

CK, T1, and T2 differed greatly. The results indicated that soil texture and $\mathrm{N}$ fertilisation were important factors affecting changes in soil bacterial communities.

Relative abundance of dominant bacterial communities at different taxonomic levels. The RDP classifier Bayesian algorithm was used to classify and analyse $97 \%$ of OTU representative sequences at similar taxonomic levels. The community composition and relative abundance of bacteria in each sample were calculated at various taxonomic levels (phylum, class, order, family, genus, and species) (Table 4).

Under the different soil textures in CK treatments, the relative abundance of dominant bacterial communities at these six taxonomic levels was highest in clay loam followed by loam soil and sandy loam, the latter two of which were similar to each other. In the T1 treatment, the relative abundance of dominant communities did not significantly differ between soils of different textures at the six taxonomic levels. In the T2 treatment, the dominant abundance of bacteria at five taxonomic levels (phylum, class, order, family, and genus) was highest in clay loam followed by loam soil, and was lowest in sandy loam. In contrast, at the species level, the relative abundance of dominant communities was lowest in clay loam and highest in sandy loam. When comparing different fertilisation treatments in the same soil texture, $\mathrm{N}$ fertilisation was found to have a bigger impact on the relative abundance of dominant communities in clay loam than in the other two soils at the class, order, family, and genus levels. Moreover, $\mathrm{N}$ fertilisation reduced the relative abundance of dominant bacterial communities in clay loam and loam soils, but did not have the same effect in sandy loam soil.

Analysis of bacterial community composition. Sample sequences were classified at the phylum level, with a total of 39 taxa identified; phyla with relative abundance above $1 \%$ are shown in Fig. 4 . Both soil texture and $\mathrm{N}$ fertilisation significantly influenced the relative abundance of the most prominent bacterial phyla in the soil samples. Most bacterial phyla and classes detected in the samples were affected by soil texture, regardless of $\mathrm{N}$ fertilisation.

The dominant bacterial phyla differed among soil types. In loam soil, Proteobacteria (32.10-34.75\%), Firmicutes (17.91-25.58\%), Acidobacteria (14.20-23.79\%), and Bacteroidetes (5.02-9.98\%) were the dominant phyla, whereas in clay loam soil, abundances of Firmicutes (20.41-50.94\%), Proteobacteria (20.09-35.17\%), Acidobacteria (13.04-14.32\%), and Bacteroides (5.01-5.79\%) exceeded 5\%. In sandy loam, abundances of five species of bacteria exceeded 5\%, consisting of Proteobacteria (24.38-38.96\%), Firmicutes (17.65-28.31\%), Acidobacteria (12.79-22.31\%), Chloroflexi (4.95-7.59\%), and Actinobacteria (2.69-9.45\%). 

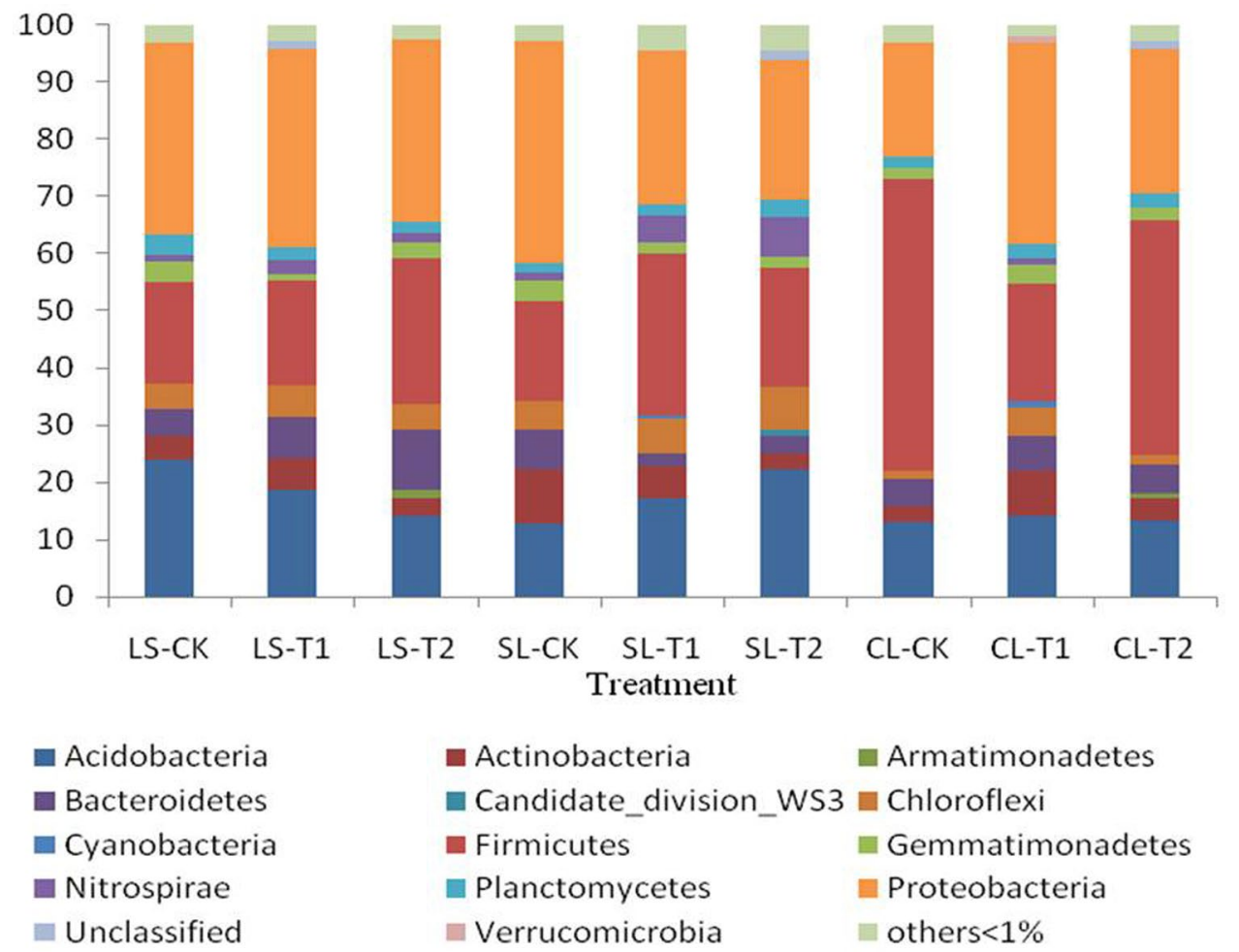

Figure 4. Relative abundance of the bacterial predominant phyla for different samples. $L S$ loam soil, $S L$ sandy loam, $C L$ clay loam, $C K$ no fertiliser, $T 1$ conventional fertilisation, $T 2$ no nitrogen fertiliser.

$\mathrm{N}$ fertilisation had a limited and variable effect on the abundances of the primary bacterial phyla. Compared with the loam soil CK, the T1 and T2 fertilisation treatments had no significant effect on the abundance of Proteobacteria, whereas Acidobacteria declined by $31.09 \%$ and Firmicutes and Bacteroidetes increased by $44.39 \%$ and $26.31 \%$, respectively.

To further examine the effects of soil texture and $\mathrm{N}$ fertilisation on soil bacterial community structure, the classification and relative abundance of OTUs were analysed at the genus level. A total of 43 genera were detected in all $\mathrm{N}$ fertilisation-soil texture combinations (Fig. 5). The number of species and abundances of bacteria differed among treatments, indicating that the bacterial distribution in the various samples was extremely diverse. Of these, Lactococcus (11.52-46.59\%), Pseudomonas (1.21-7.47\%), Subgroup_6_norank (1.49-9.74\%), Unclassified (2.48-6.16\%), Uncultured (9.98-20.60\%), and Uncultured_norank (1.00-2.91\%) were the most common groups of bacteria in the soils of all treatments, while Uncultured and Lactococcus were the dominant types in all treatments. In addition, the top three unique types in loam, sandy loam, and clay loam soils in the CK treatment were Subgroup_6_norank (9.74\%), Xanthomonas (8.45\%), and Acinetobacter (4.46\%); in the T1 treatment, Unclassified (5.33\%), Bacillus(8.49\%), and Xanthomonas (8.19\%); and in the T2 treatment, Massilia (5.58\%), Unclassified (6.16\%), and Pseudomonas(7.47\%).

Relative abundance of $\mathrm{N}$-transforming bacteria in soils of different textures. The effects of soil texture and $\mathrm{N}$ fertilisation on the estimated OTUs of soil N-transforming bacteria are shown in Table 5. Bacillus, Nitrobacter, Nitrosospira, Nitrospira, and Rhizobium were the most common N-transforming bacterial genera identified in all soil samples. Bacillus and Nitrospira OTUs were more abundant than those of the other N-transforming bacteria; the OTUs of Nitrosospira and Rhizobium in clay loam soil were higher than those in loam and sandy loam soils, while the OTUs of Bacillusin sandy loam soil were the highest among all soil types. In addition, Bacillus and Nitrobacter were both higher in sandy loam soil than in the other soils. In terms of the fertilisation treatments, the OTUs of Bacillus, Nitrosospira, and Nitrobacter were consistently higher in T1 than in T2 and CK across all soil types, while the OTUs of Nitrospira were slightly lower in T1 than in T2 and the OTUs of Rhizobium were highest in CK.

\section{Discussion}

Soil texture is an important environmental factor affecting the uptake and accumulation of mineral elements in flue-cured tobacco ${ }^{24}$. Characteristics associated with tobacco leaf quality are most prominent in plants grown in sandy and loam soils, and least prominent in plants grown in heavy clay soil ${ }^{25}$. The chemical components of tobacco leaves and aroma-notes were positively correlated with soil sand content and negatively correlated with silt and clay content (unpublished data). Nitrogen is the most important mineral influencing the growth and development of flue-cured tobacco plants and leaf quality ${ }^{26,27}$. Absorption and uptake of $\mathrm{N}$ differ in tobacco 


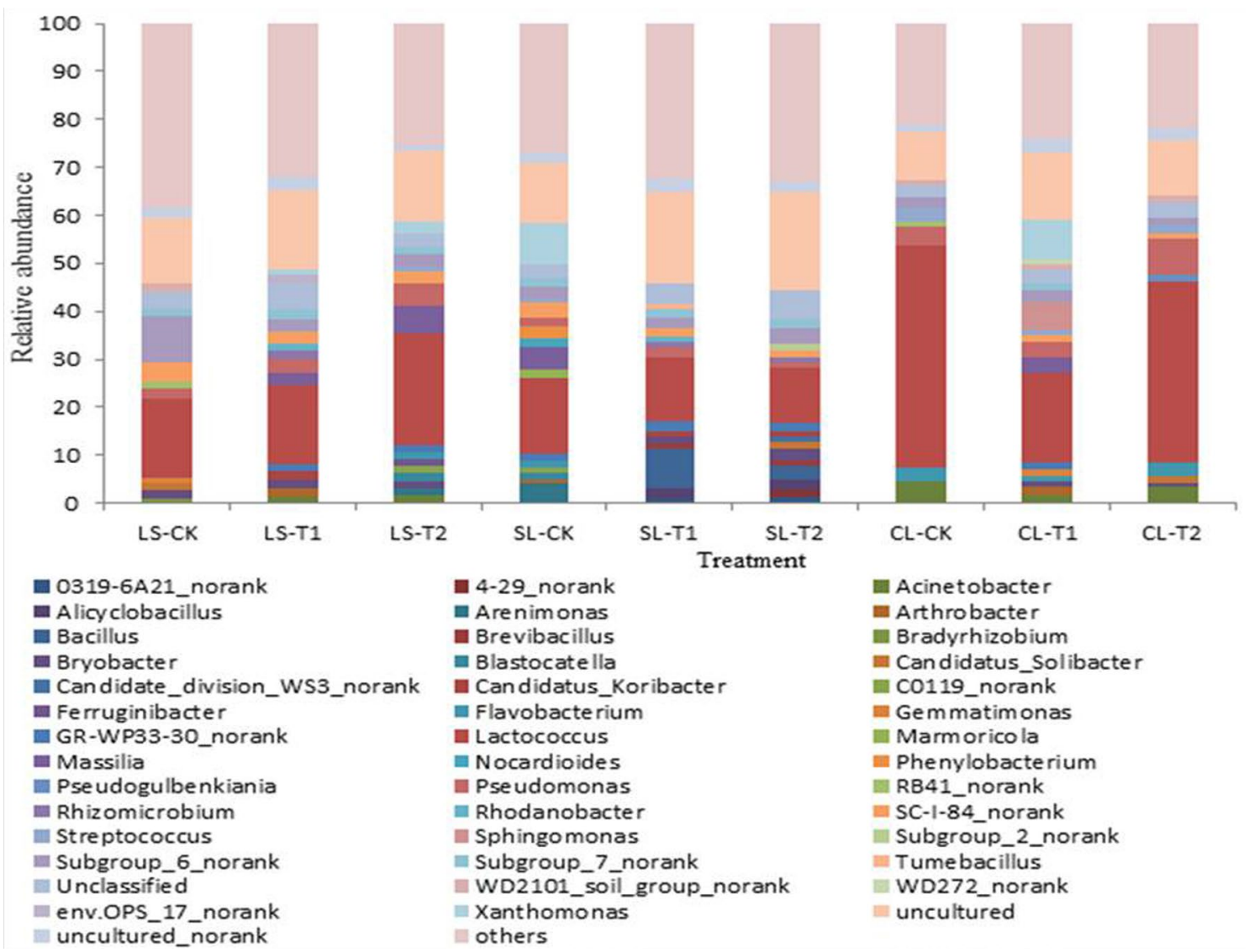

Figure 5. Relative abundance of the bacterial predominant genus for different samples.

\begin{tabular}{|c|c|c|c|c|c|c|c|c|c|}
\hline \multirow[b]{2}{*}{ Genus } & \multicolumn{9}{|c|}{ Treatment } \\
\hline & CL-CK & CL-T1 & CL-T2 & LS-CK & LS-T1 & LS-T2 & SL-CK & SL-T1 & SL-T2 \\
\hline Bacillus & 17 & 35 & 15 & 5 & 24 & 4 & 18 & 884 & 321 \\
\hline Nitrobacter & 5 & 7 & 2 & 6 & 11 & 7 & 3 & 12 & 5 \\
\hline Nitrosospira & 10 & 22 & 10 & 4 & 44 & 5 & 6 & 9 & 1 \\
\hline Nitrospira & 54 & 27 & 74 & 26 & 24 & 26 & 28 & 52 & 98 \\
\hline Rhizobium & 23 & 3 & 3 & 15 & 1 & 5 & 3 & 3 & 3 \\
\hline
\end{tabular}

Table 5. Estimated OTUs of major $\mathrm{N}$ transformation bacteria at the genus level of the $16 \mathrm{~S}$ rRNA gene libraries for clustering at $97 \%$ identity.

grown in soils with different characteristics ${ }^{28,29}$, which further affects the formation and accumulation of chemical components and aromatic substances in tobacco leaves ${ }^{30-32}$. Our results suggested that uptake of soil $\mathrm{N}$ by flue-cured tobacco increased gradually over the course of the growing period, but was always lower in clay loam than in loam soil and sandy loam soils; in contrast, $\mathrm{N}$ uptake was significantly higher in sandy loam soil and clay loam soils once plants had reached maturity. Use efficiency of $\mathrm{N}$ was lower in sandy loam soil in early growth stages and increased gradually over later stages, whereas in clay loam and loam soils, $\mathrm{N}$ use efficiency increased in early growth stages and decreased in later stages. With the use of ${ }^{15} \mathrm{~N}$ isotopes, it has been shown that tobacco is able to absorb only about $20.9 \%$ of the $\mathrm{N}$ applied via fertilizer ${ }^{33}$, soil nitrogen is mainly nitrogen absorbed by flue-cured tobacco. The difference in the extent of $\mathrm{N}$ mineralisation between different textured soils in different growth stages of flue-cured tobacco was very significant. In clay loam and sandy loam soil, nitrogen mineralization rate was higher in the early stage and lower in the later stage, which is conducive to the formation of flue-cured tobacco yield and quality ${ }^{34}$. Most of the $\mathrm{N}$ in the soil is organic $\mathrm{N}$, which directly determines the $\mathrm{N}$ supply capacity of the soil. The soil texture mainly provides protection for the soil organic matter by controlling the activities of aerobic bacteria and the combination of soil organic matter and soil clay, thus affecting the mineralisation of soil $\mathrm{N}^{35}$. Some studies have pointed out that the microbial biomass of $\mathrm{C} / \mathrm{N}$ in sandy loam is higher, whereas that in clay and loam is relatively low, and that it increases with an increase in the mineralisation rate of microbial biomass $\mathrm{N}^{36}$. Therefore, the $\mathrm{N}$ mineralisation and supply capacity of sandy loam is higher 
than that of loam soil and clay loam, and clay loam has the lowest $\mathrm{N}$ mineralisation rate and the lowest $\mathrm{N}$ supply capacity among these textured soils.

From the Table 2, it could be found that $\mathrm{N}$ accumulation in root and stalk continually increased during the whole growth period in three types of soil, while $\mathrm{N}$ accumulation in leaves increased until ceiling stage for the plants in loam soil and clay loam, then decreased dramatically. Compared with those at ceiling stage, $\mathrm{N}$ in leaves lost $36 \%, 47 \%$ respectively. The nitrogen absorption of tobacco mainly occurred at the early stage of tobacco growth. At the later stage of tobacco growth (after topping stage), tobacco leaves begin to age and turn yellow, and nitrogen is diluted and transported in the leaves, and the ability of tobacco plants to absorb nitrogen gradually weakens, and a part of $\mathrm{N}$ is transferred from leaves to root and stalk ${ }^{37}$. Each treatment has three repetitions, but it is difficult to remove the spatial variability and tobacco growth differences in field experiment, which may affect the $\mathrm{N}$ accumulation in tobacco leaves and cause some variances among different treatments. So, to quantify the $\mathrm{N}$ accumulation and distribution of different sources of $\mathrm{N}$ in flue-cured tobacco organs accurately at different growth stages, a long-term field experiment with multiple soil types was necessary and desirable in further studies.

Microorganisms, primarily bacteria, are common in soils. Bacterial communities are important for the health and productivity of soil ecosystems and have great potential as novel indicators of environmental disturbance $\mathrm{e}^{38}$. The results of our analysis indicated that soil bacterial community structure and composition were greatly influenced by soil texture and $\mathrm{N}$ fertilisation. Bacterial community richness and diversity were much higher in sandy loam and loam soils than in clay loam soil, a finding consistent with the results of previous research ${ }^{39,40}$. This divergence in bacterial communities among soil types could be due to differences in soil nutrient availability and particle size fractions ${ }^{41}$. Moreover, soil texture can regulate the size and structure of soil bacterial communities by influencing the extent and connectivity of microhabitats; there is also strong evidence that spatial isolation imparted by fragmented microhabitats in soil plays a large role in determining soil bacterial diversity ${ }^{42}$. Nitrogen fertilisation is also an important factor influencing soil bacterial diversity. The changes in soil bacteria diversity and richness resulting from $\mathrm{N}$ application observed in this study could be related to changes in soil $\mathrm{pH}$, given that soil nutrient availability, microbial properties, and $\mathrm{pH}$ are concomitantly altered by $\mathrm{N}$ fertilisation ${ }^{15,43,44}$. Except for clay loam, application of $\mathrm{N}$ fertiliser reduced bacterial community diversity regardless of soil texture. Previous studies have shown that $\mathrm{N}$ fertilisation often leads to declines in microbial community diversity and species richness ${ }^{43-45}$.

Soil texture and $\mathrm{N}$ fertilisation were found to have significant effects on soil bacterial community structure, and the relative proportions of the dominant bacterial phyla differed with soil type. Proteobacteria, Firmicutes, andAcidobacteriawere the most abundant bacteriain all of the soils, while Bacteroidetes, Chloroflexi, and Actinobacteria were also common, a pattern similar to that reported in previous studies ${ }^{46,47}$. Acidobacteria, a phylum composed of acidophilic species, are among the most ubiquitous bacteria in soil ecosystems $\mathrm{s}^{48}$, the abundances of which are negatively correlated with soil nitrate content and strongly correlated with soil $\mathrm{pH}^{49-51}$. A previous $\mathrm{N}$ addition study found that alterations in soil bacterial community structure were directly related to soil $\mathrm{N}$ concentration, but not to soil $\mathrm{pH}^{52}$, with the abundance of Firmicutes increasing in loam and sandy loam soils but declining in clay loam soil compared to control samples. Studies have shown that Proteobacteria and Nitrospirae are primarily involved in soil nitrification ${ }^{53,54}$, while members of the Bacteroidetes have been linked with soil denitrification ${ }^{55,56}$. In the present study, the relative abundance of Nitrospirae in the soil was initially low but significantly increased following application $\mathrm{N}$ fertiliser (Fig. 4), while the abundance of Bacteroidetes also increased, at least to a certain extent. Actinobacteria play key roles in soil ecosystem function, including the decomposition of soil organic matter, and they secrete antibiotics in response to the presence of pathogenic bacteria in the soil ${ }^{57}$. The abundance of Actinobacteria has been shown to be positively correlated with soil $\mathrm{pH}$, organic matter content, and total Ncontent ${ }^{57-59}$, and in our study, the proportion of Actinobacteria rose in loam soil and clay loam soils, but fellin sandy loam.

Microorganisms can utilise $\mathrm{N}$ deriving from a wide range of organic and mineral compounds. Soil texture and $\mathrm{N}$ fertilisation affect soil $\mathrm{N}$ availability and $\mathrm{N}$ uptake by influencing the microbial communities that determine rates of $\mathrm{N}$ transformation in soil. Numerous genera of soil bacteria exhibit $\mathrm{N}$ transformation activity, including Nitrosomonas, Nitrosococcus, Nitrosospira, Nitrosovibrio, Nitrosolobus, Alcaligenes, Arthrobacter, Aspergillus, Nitrobacter, Nitrococcus, Nitrococcus, Nitrospira, Bacillus, Rhizobium, among many others ${ }^{60-64}$. Of these, Bacillus, Nitrobacter, Nitrosospira, Nitrospira, and Rhizobium were the most common genera identified in this study (Table 5). In particular, Bacillus OTUS were higher in sandy loam than in loam and clay loam, possibly accounting for the greater $\mathrm{N}$ mineralisation and supply capacity of sandy loam soils. Previous studies have reported that soil texture properties shape soil bacterial and protist communities ${ }^{39}$; here, we found that the soil bacterial community, and especially those involved in soil $\mathrm{N}$ transformation, were directly affected by $\mathrm{N}$ fertilisation, to which they responded by increasing $\mathrm{N}$ availability, a result consistent with that of previous research ${ }^{65,66}$. In addition, $\mathrm{N}$ fertilisation affects soil bacterial communities indirectly by altering soil properties, such as $\mathrm{pH}$ and organic matter ${ }^{67}$. As such, $\mathrm{N}$ availability in the soil and $\mathrm{N}$ use efficiency by tobacco is likely to be strongly dependent on the composition of $\mathrm{N}$ transforming bacteria in the soil, constituting a potentially important topic for future study.

\section{Conclusion}

Our study showed that in soils of different textures, $\mathrm{N}$ uptake and utilisation of flue-cured tobacco was highest in sandy loam soil, followed in order by loam and clay loam soils. In addition, the $\mathrm{N}$ supply capacity of clay loam was weak, and thus it was necessary to regulate the mineralisation of soil $\mathrm{N}$ and increase the supply of fertiliser $\mathrm{N}$. Tobacco plants growing in sandy loam had the highest $\mathrm{N}$ utilisation rate, followed by plants growing in loam and clay loam soils. However, our results suggest that the amount of $\mathrm{N}$ fertiliser applied to sandy loam soil should be strictly regulated. 
Both non-fertilisation and lack of $\mathrm{N}$ fertilisers can reduce soil bacterial abundance in tobacco fields to various degrees. Moreover, the bacterial diversity in sandy loam soil was higher than that in the other two soils, whereas the bacterial species in loam and clay loam soils were relatively uniform, with considerably lower diversity. Both soil texture and $\mathrm{N}$ fertilisation had significant effects on soil bacterial community structure: members of the Proteobacteria, Acidobacteria, Firmicutes, Bacteroidetes, Actinobacteria, and Chloroflexi were the major $\mathrm{N}$ transformation bacteria in all soil textures. Moreover, the relative abundances of these bacteria were also dependent on soil type and $\mathrm{N}$ fertilisation, which would lead to differences in $\mathrm{N}$ availability for and use efficiency by tobacco growing in these soils.

Received: 5 August 2020; Accepted: 8 November 2021

Published online: 22 November 2021

\section{References}

1. Smil, V. Nitrogen in crop production: An account of global flows. Glob. Biogeochem. Cycles 13, 647-662 (1999).

2. Zheng, W. et al. Combining controlled-release urea and normal urea to improve the nitrogen use efficiency and yield under wheatmaize double cropping system. Field Crop Res. 197, 52-62 (2016).

3. Feng, J. et al. Integrated assessment of the impact of enhanced-efficiency nitrogen fertilizer on $\mathrm{N}_{2} \mathrm{O}$ emission and crop yield. Agric. Ecosyst. Environ. 231, 218-228 (2016).

4. Savci, S. An agricultural pollutant: Chemical fertilizer. Int. J. Environ. Sci. Dev. 3(1), 73 (2012).

5. Ju, X. T., Kou, C. L., Zhang, F. S. \& Christie, P. Nitrogen balance and groundwater nitrate contamination: Comparison among three intensive cropping systems on the North China Plain. Environ. Pollut. 143(1), 117-125 (2006).

6. Hu, Y., Moiwo, J. P., Yang, Y., Han, S. \& Yang, Y. Agricultural water-saving and sustainable groundwater management in Shijiazhuang Irrigation District, North China Plain. J. Hydrol. 393(3-4), 219-232 (2010).

7. Cui, Z., Chen, X. \& Zhang, F. Current nitrogen management status and measures to improve the intensive wheat-maize system in China. Ambio 39(5-6), 376-384 (2010).

8. Hassink, J. Effect of soil texture and grassland management on soil organic $\mathrm{C}$ and $\mathrm{N}$ rates of $\mathrm{C}$ and $\mathrm{N}$ mineralization. Soil Biol. Biochem. 26, 1221-1231 (1994).

9. Nyiraneza, J., Cambouris, A. N., Ziadi, N., Tremblay, N. \& Nolin, M. C. Spring wheat yield and quality related to soil texture and nitrogen fertilization. Agron. J. 104(3), 589-599 (2012).

10. Ritz, K., Black, H. I. J., Campbell, C. D., Harris, J. \& Wood, C. Selecting biological indicators for monitoring soils: A framework for balancing scientific and technical opinion to assist policy development. Ecol. Indic. 9, 1212-1222 (2009).

11. Tang, Y. et al. Changes in nitrogen-cycling microbial communities with depth in temperate and subtropical forest soils. Appl. Soil. Ecol. 124, 218-228 (2018).

12. Tahovská, K. et al. Microbial N immobilization is of great importance in acidified mountain spruce forest soils. Soil Biol. Biochem. 59, 58-71 (2013).

13. Wang, Q. et al. Long-term fertilization changes bacterial diversity and bacterial communities in the maize rhizosphere of Chinese Mollisols. Appl. Soil. Ecol. 125, 88-96 (2018).

14. Zhou, Z. F. et al. Abundance and community structure of ammonia-oxidizing bacteria and archaea in purple soil under long-term fertilization. Eur. J. Soil Biol. 60, 24-33 (2014).

15. Geisseler, D. \& Scow, K. M. Long-term effects of mineral fertilizers on soil microorganisms: A review. Soil Biol. Biochem. 75, 54-63 (2014).

16. Liu, M. S. et al. Nitrogen leaching greatly impacts bacterial community and denitrifiers abundance in subsoil under long-term fertilization. Agric. Ecosyst. Environ. 294, 106885 (2020).

17. Ying, J. Y. et al. Contrasting effects of nitrogen forms and soil $\mathrm{pH}$ on ammonia oxidizing microorganisms and their responses to long-term nitrogen fertilization in a typical steppe ecosystem. Soil Biol. Biochem. 107, 10-18 (2017).

18. Naveed, M. et al. Spatial variability of microbial richness and diversity and relationships with soil organic carbon, texture and structure across an agricultural field. Appl. Soil. Ecol. 103, 44-55 (2016).

19. Seaton, F. M. et al. Soil textural heterogeneity impacts bacterial but not fungal diversity. Soil Biol. Biochem. 144, 107766 (2020).

20. Zhang, J. et al. Effects of tobacco planting systems on rates of soil $\mathrm{N}$ transformation and soil microbial community. Int. J. Agric. Biol. 19(5), 992-998 (2017).

21. Karaivazoglou, N. A., Tsotsolis, N. C. \& Tsadilas, C. D. Influence of liming and form of nitrogen fertilizer on nutrient uptake, growth, yield, and quality of Virginia (flue-cured) tobacco. Field Crops Res. 100(1), 1-60 (2007).

22. Chen, Z. Y., Wen, X. F. \& Hu, G. H. Nuclear Technology and Its Application in Agricultural Science 466-484 (Science and Technology Press, 1983).

23. Klindworth, A. et al. Evaluation of general $16 \mathrm{~S}$ ribosomal RNA gene PCR primers for classical and next-generation sequencingbased diversity studies. Nucleic Acids Res. 41(1), el (2013).

24. Chen, Y. et al. Analysis on effect of dynamic changes of main nutrients in different texture soils on flue-cured tobacco. Hubei Agric. Sci. 50(11), 4361-4364 (2011).

25. Song, Y. L. Study on the Effects of Soil Conditions on the Formation of Tobacco with High Quality and Good Characteristics (Henan Agricultural University, 2014).

26. Rosa, M., Fabio, C. \& Renato, C. Nitrogen requirements for flue-cured tobacco. Agron. J. 98(3), 666-674 (2006).

27. Lu, Y. X. Effects of Ammonia on Growth, Nutrient Absorption, Distribution and Quality of Flue-Cured Tobacco (China Agricultural University, 2003).

28. Hawks, S. N. \& Collins, W. K. Principle of Flue-Cured Tobacco Production (North Carolina State University Press, 1983).

29. Bernd, S., Harald, S., Reinhold, G. \& Norbert, C. Root production and root mortality of winter wheat grown on sandy and loamy soils in different farming systems. Biol. Fertil. Soils 33, 331-339 (2001).

30. Dai, M. Relationship Between Climate Factors and Leaf Chemical Composition in Some Tobacco Leaf Production Areas in China 46-55 (Guangdong science and Technology Press, 1997).

31. Zhang, X. Y. et al. Effects of different forms of nitrogen fertilizer on predominant enzymes of $\mathrm{C}$ and $\mathrm{N}$ metabolism in red and rice soils of flue-cured tobacco. J. Yunnan Agric. Univ. 20(2), 225-230 (2005).

32. Xiao, J. X. et al. The influence of climatic ecology factors on the yield and quality of flue-cured tobacco and the countermeasures of planting tobacco in Jiangxi. Chin. J. Eco-Agric. 11(4), 158-160 (2013).

33. Hou, M. M. et al. Study on nitrogen utilization efficiency of flue-cured tobacco with ${ }^{15} \mathrm{~N}$ tracing technique. Adv. Mater. Res. 518-523, 520-524 (2012).

34. Lu, L. et al. Effect of soil character on nitrogen mineralization of tobacco soil. Chin. Agric. Sci. Bull. 27(3), 147-153 (2011) ((in Chinese)).

35. Hassink, T. et al. Relationships between soil texture, physical protection of organic matter, Soil Biota and C and N mineralization in grassland soils. Geoderma 57, 105-128 (1993). 
36. Hassink, J. Relationship between the amount and the activity of the microbial biomass in Dutch grassland soils: Comparison of the fumigation-incubation method and the substrate-induced respiration method. Soil Biol. Biochem. 25(5), 533-538 (1993).

37. Zhao, G. W. Study on the Biology and Qualitative Characteristics of Flue-Cured Tobacco Leaves During the Growth and Development. Ph.D. Thesis, Northeast Forestry University (2007).

38. Hermans, S. M. et al. Bacteria as emerging indicators of soil condition. Appl. Environ. Microbiol. 83(1), e02826 (2017).

39. Obayomi, O. et al. Soil texture and properties rather than irrigation water type shape the diversity and composition of soil microbial communities. Appl. Soil Ecol. 161, 103834 (2021).

40. Amador, J. A. \& Atoyan, J. A. Structure and composition of leachfield bacterial communities: Role of soil texture, depth and septic tank effluent inputs. Water 4, 707-719 (2012).

41. Sessitsch, A. et al. Microbial population structures in soil particle size fractions of a long-term fertilizer field experiment. Appl. Environ. Microbiol. 67, 4215-4224 (2001).

42. Chau, J. F. Bacterial Diversity in Soil as a Function of Soil Texture. Doctoral Dissertations, AAI3377016 (2009).

43. Fierer, N. \& Jackson, R. B. The diversity and biogeography of soil bacterial communities. Proc. Natl. Acad. Sci. USA 103, 626-631 (2006).

44. Yevdokimov, I. et al. Changes in microbial community structure in soil as a result of different amounts of nitrogen fertilization. Biol. Fertil. Soils 44, 1103-1110 (2008).

45. Suding, K. N. et al. Functional-and abundance-based mechanisms explain diversity loss due to N fertilization. Proc. Natl. Acad. Sci. USA 102, 4387-4392 (2005).

46. Hartmann, A. et al. Plant-driven selection of microbes. Plant Soil 321(1-2), 235-257 (2009).

47. Zhang, Y. J. et al. Changes of soil enzyme activities and microorganism amounts at different growing stages of flue-cured tobacco. Soils 42, 39-44 (2010).

48. Janssen, P. H. Identifying the dominant soil bacterial taxa in libraries of $16 \mathrm{~S}$ rRNA and $16 \mathrm{~S}$ rRNA genes. Appl. Environ. Microbiol. 72, 1719-1728 (2006).

49. Song, Y. N. \& Lin, Z. M. Abundance and community composition of ammonia-oxidizers in paddy soil at different nitrogen fertilizer rates. J. Integr. Agric. 13(4), 870-880 (2014).

50. Jones, R. T. et al. A comprehensive survey of soil acidobacterial diversity using pyrosequencing and clone library analyses. ISMEJournal 3, 442-453 (2009).

51. Liu, C. et al. Acidobacteria community responses to nitrogen dose and form in Chinese fire plantations in Southern China. Curr. Microbiol. 74(3), 396-403 (2017)

52. Wang, Y. et al. Comparison of the levels of bacterial diversity in freshwater, intertidal wetland, and marine sediments by using millions of illumina tags. Appl. Environ. Microbiol. 78(23), 8264-8271 (2012).

53. Burrell, P., Keller, J. \& Blackall, L. Characterisation of the bacterial consortium involved in nitrite oxidation in activated sludge. Water Sci. Technol. 39(6), 45-52 (1999).

54. Lee, H. W. et al. Molecularcharaterization of microbial community in nitrate-removing activated sludge. FEMS Microbiol. Ecol. 41(2), 85-94 (2002).

55. Häni, H., Siegenthaler, A. \& Candinas, T. Soil effects due to sewage sludge application in agriculture. In Fertilizers and Environment 267-274 (Springer, 1996).

56. Wang, Y. \& Hu, C. S. Research advances on community structure and function of denitrifiers. Chin. J. Eco-Agric. 18(6), 1378-1384 (2010).

57. Lauber, C. L. et al. The influence of soil properties on the structure of bacterial and fungal communities across land-use types. Soil Biol. Biochem. 40(9), 2407-2415 (2008).

58. Liu, J. et al. High throughput sequencing analysis of biogeographical distribution of bacterial communities in the black soils of northeast China. Soil Biol. Biochem. 70, 113-122 (2014).

59. Dai, Z. et al. Long-term nitrogen fertilization decreases bacterial diversity and favors the growth of Actinobacteria and Proteobacteria in agro-ecosystems across the globe. Glob. Change Biol. 24(8), 3452-3461 (2018).

60. Watson, S. W. et al. Nitrifying Bacteria//Bergey's Manual of Systematic Bacteriology Vol. 3, 1808-1834 (Williams \& Wilkins, 1989).

61. Purkhold, U. et al. Phylogeny of all recognized species of ammoniaoxidizers based on comparative 16S rRNA and amoA sequence analysis: Implications for molecular diversity surveys. Appl. Environ. Microbiol. 66(12), 5368-5382 (2000).

62. Prosser, J. I. Autotrophic nitrification in bacteria. Adv. Microb. Physiol. 30, 125-181 (1989).

63. Laurent, P. et al. $16 \mathrm{~S}$ rDNA analysis for characterization of denitrifying bacteria isolated from three agricultural soils. FEMS Microbiol. Ecol. 34, 121-128 (2000).

64. Lonis, A. S. \& Maja, V. V. Five years of nitrite removal, denitrificaion and carbon dynamies in a denitrification wall. Water Res. 35(14), 3473-3477 (2001).

65. Dominchin, M. F. et al. Impact of N-fertilization and peanut shell biochar on soil microbial community structure and enzyme activities in a Typic Haplustoll under different management practices. Eur. J. Soil Biol. 104, 103298 (2021).

66. María, A. I. et al. Land cover does not affect microbial and plant response to glyphosate and nitrogen application in the Pampas (Argentina). Appl. Soil Ecol. 160, 103863 (2021).

67. Guo, Q. X. et al. Plant-plant interactions and N fertilization shape soil bacterial and fungal communities. Soil Biol. Biochem. 128, $127-138$ (2019).

\section{Acknowledgements}

This work was funded by the Agricultural Science and Technology Innovation Program of China (ASTIPTRIC06), the National Natural Science Foundation of China (41201291), the Science and Technology Project of Shanghai Tobacco Group (20183100010), the Science and Technology Project of Anhui Tobacco Company (20190551003), the Science and Technology Project of Chenzhou Branch of Hunan Tobacco Company (No.201945). We thank Yansong Xiao and Jiuquan Zhang for help with revising the manuscript. And we would like to thank Editage (www.editage.cn) for English language editing.

\section{Author contributions}

J.Z. designed the experiments. M.Z. and P.Z. carried out the experiments and wrote the manuscript and contributed equally to this manuscript. J.Z., L.X., Q.Z., X.C., and S.C. performed the experiments and analysed the data. Z.Z. and F.K. critically corrected the manuscript. All authors have reviewed the manuscript.

\section{Competing interests}

The authors declare no competing interests. 


\section{Additional information}

Correspondence and requests for materials should be addressed to J.Z.

Reprints and permissions information is available at www.nature.com/reprints.

Publisher's note Springer Nature remains neutral with regard to jurisdictional claims in published maps and institutional affiliations.

(c) (1) Open Access This article is licensed under a Creative Commons Attribution 4.0 International License, which permits use, sharing, adaptation, distribution and reproduction in any medium or format, as long as you give appropriate credit to the original author(s) and the source, provide a link to the Creative Commons licence, and indicate if changes were made. The images or other third party material in this article are included in the article's Creative Commons licence, unless indicated otherwise in a credit line to the material. If material is not included in the article's Creative Commons licence and your intended use is not permitted by statutory regulation or exceeds the permitted use, you will need to obtain permission directly from the copyright holder. To view a copy of this licence, visit http://creativecommons.org/licenses/by/4.0/.

(C) The Author(s) 2021 